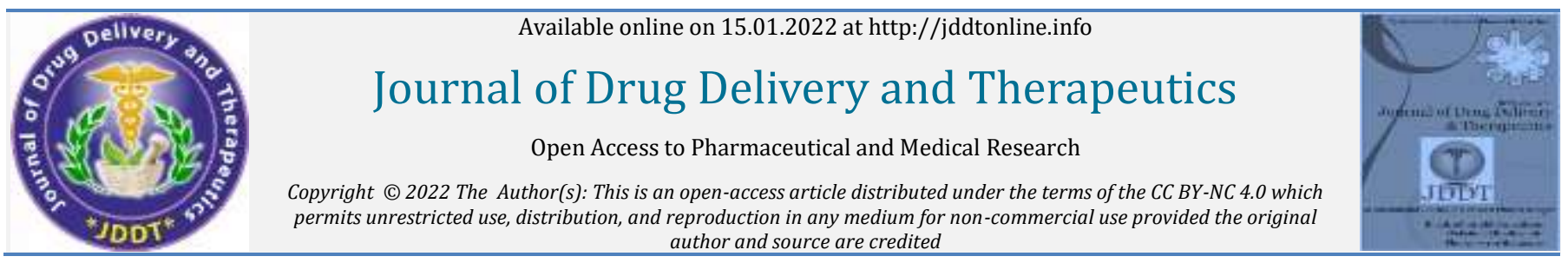
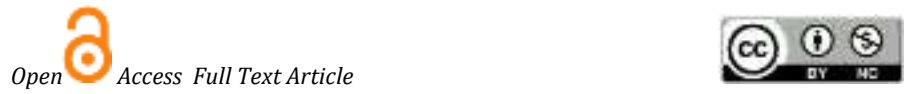

Research Article

\title{
Phytochemical and Antimicrobial Activity of Ocimum suave Against Selected Human Pathogenic Bacteria
}

\author{
Thierry Habyarimana*ii), Parfait Cyuzuzo, Clémentine Yamukujije, Callixte Yadufashije (ii), François N. \\ Niyonzima
}

Department of Biomedical Laboratory Sciences, INES-Ruhengeri, Musanze, Rwanda

\section{Article Info:}

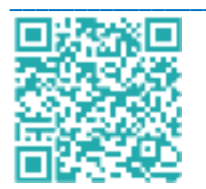

\section{Article History:}

Received 04 December 2021

Reviewed 02 January 2022

Accepted 08 January 2022

Published 15 January 2022

\section{Cite this article as:}

Habyarimana T, Cyuzuzo P, Yamukujije C, Yadufashije C, Niyonzima FN, Phytochemical and Antimicrobial Activity of Ocimum suave Against Selected Human

Pathogenic Bacteria, Journal of Drug Delivery and

Therapeutics. 2022; 12(1):123-128

DOI: http://dx.doi.org/10.22270/jddt.v12i1.5291

\section{*Address for Correspondence:}

Thierry Habyarimana, Department of Biomedical Laboratory Sciences, INES-Ruhengeri, Musanze, Rwanda

ORCID ID: https://orcid.org/0000-0001-5488-5578

\author{
Abstract
}

Worldwide, the use of antibiotics is losing effectiveness due to the substantial resistance to the antimicrobial developed by many pathogenic bacteria. African populations including Rwanda, use frequently traditional medicine for primary care. This study aimed to determine the phytochemicals and the antimicrobial activity of Ocimum. suave (O. suave) against selected human pathogenic bacteria (two strains of $S$. aureus, P. aeruginosa, two strains of E. coli, S. pneumonia, $S$. pyogene, $K$. oxytoca, $H$. influenza, $S$. sonei). The leaf and stem extracts were prepared using maceration technique. The antimicrobial activities of extracts were evaluated using the impregnated disc and agar well diffusion methods. The tests revealed the presence of phytochemical substances such as tannins, flavonoids, saponins, steroids alkaloids and phenolics in leaves and only saponins in stem. S. aureus ATCC 43300 was the most sensitive while $H$. influenza was the most resistant among the microorganisms tested. Aqueous and methanolic crude extract of $O$. suave displayed maximum diameter of inhibition zone against bacteria (9-26.5 $\mathrm{mm}$ and 9-23.5 respectively) and Two-way ANOVA showed statistical significance difference between their means. T-test was used in comparison with standards antibiotics and showed that the distilled water extracts exhibited much higher activity against all tested organisms than activity of streptomycin. Combination of distilled water and methanol extracts with streptomycin revealed synergistic activity against E. coli ATCC 25922 and S. pneumonia ATCC 49618. The leaves of $O$. suave have a great potential antibacterial activity and should be fully explored for future treatment.

Keywords: phytochemical; antimicrobial activity; Ocimum suave, Rwanda

\section{INTRODUCTION}

Antibiotics play a significant role in reducing the burden of infectious diseases all over the world. However, the effectiveness of treatment of infections has become a global public health issue due to the Antimicrobial resistance (AMR) 1,2 . Low- and middle-income countries (LMICs) remain the most affected by both the infectious disease and the growing threat of antibiotic resistance where about $4 \mathrm{M}$ of deaths are estimated by 2050 due to the AMR ${ }^{3-5}$. African traditional medicine has been used in the management of infectious diseases and is still the most widely as primary healthcare needs ${ }^{6}$. According to the World Health Organization (WHO), 80\% of the people in the developing countries including Rwanda rely on traditional medicinal plants for their health care ${ }^{7}$. While African region continues to register an alarming rate of AMR, this region abounds in medicinal plants that have proven to be a source of new antibiotics or constitute an alternative to the current drugs ${ }^{8}$. Therefore, traditional medicinal plants could be exploited as a source for drug development and might play a role in overcoming the growing problem of resistance and the toxicity of the currently commercial antibiotics 9. However, phytochemical and antibacterial analysis of medicinal plants remain extensively unexplored.

Ocimum suave is abundant in different countries of the world including Rwanda (locally known as Umwenya) where is widely grown in gardens and forests ${ }^{10}$. It is a flowering plant of Lamiaceae family with ascending erect, branched perennial herb and fine tomentose-pubescent 11. It is used as a traditional herb with a wide array of phytochemical constituents such as flavonoids, polyphenols, saponins, alkaloid, phenols and tannins which have been described as pharmacologically active compounds ${ }^{12}$. In addition to antipests activity, the extracts of $O$. suave have been reported to have in vitro growth of bacterial and fungal isolates ${ }^{13}$. The leave extracts have shown an antibacterial activity against Escherichia coli (E. coli), Shigella, Salmonella, Proteus Bacillus subtilis (B. subtilis), Staphylococcus aureus (S. aureus) and some fungi (Trichophyton mentagrophytes var. interdigitale) 14,15 .

In order to contribute to the growing need of developing new antibacterial agents for both Gram negative as well as Gram positive, it is necessary to investigate the chemical 
composition and antimicrobial activity of Ocimum suave growing in Musanze district, a volcanic region of Northern Province of Rwanda. Keeping this in view, the chemistry of leaves and stem extracts was assessed and the in vitro biological activity was evaluated on selected human pathogenic bacteria.

\section{MATERIALS AND METHODS}

\section{Collection of plant samples and bacterial strains}

The plant material was collected from the forests of Musanze district, Northern Province, of Rwanda. The leaves and stem with no dead parts were selectively collected and brought to the laboratory for processing. The plant parts were thoroughly washed in running water, rinsed using distilled water and finally dried at room temperature. The dried $O$. suave leaves and stems were then grounded to powder by cutter mill mixer (model/SM-400). The following ATCC bacterial strains obtained from Rwanda National Reference Laboratory were used for antimicrobial activity analysis: S. aureus ATCC 29213, $S$. aureus ATCC 43300, P. aeruginosa ATCC 27853, E. coli ATCC 25922, E. coli ATCC 35218, S. pneumonia ATCC 49618, $S$. pyogene ATCC 2399, K. oxytoca ATCC 700524, $H$. influenza ATCC 9007, S. sonei ATCC 25931.

\section{Preparation of plant extracts}

20 grams of each powdered plant material was macerated in $200 \mathrm{ml}$ of each solvent in a stoppered container. Ethanol (96\%), methanol (98\%), petroleum ether (95\%) and distilled water were used as solvents. They were allowed to stand for different maceration period (4-7days) with continuous agitation (Orbital shaker / OS-340C), until soluble matter is dissolved. The extraction was carried out at room temperature with agitation at $200 \mathrm{rpm}$.

The soaked powder-solvent mixtures were filtered twice through a Whatman No. 1 filter paper. Solutions were concentrated to $1 \mathrm{ml}$ with a rotor-evaporator (Heidolph rotary/Laborota 4010 digital) at $34-780^{\circ} \mathrm{C}$. The concentrated leave and stem extracts were stored at $4{ }^{\circ} \mathrm{C}$ for further use.

To determine the sterility of the extracts, $2 \mathrm{ml}$ of the extract was put into solidified $20 \mathrm{ml}$ of Muller Hinton agar, and incubated at $37^{\circ} \mathrm{C}$ for 24 hours. The absence of turbidity of the agar after the period of incubation confirmed a sterile extract.

\section{Qualitative phytochemical screening of 0 . suave}

The presence of resins, phenols, glycosides, saponins, tannins, flavonoids and alkaloids in the crude extract were determined according to the method defined by Harborne ${ }^{16}$.

\section{Antimicrobial susceptibility testing}

The bacterial suspensions were standardized to $10^{7}$ to $10^{8}$ cells $/ \mathrm{mL}$ as with the barium sulfate standards, a 0.5 McFarland Standard is comparable solution to a bacterial suspension of $10^{8} \mathrm{CFU} / \mathrm{ml}$. All of the tested bacteria were grown in Mueller Hinton broth at $37^{\circ} \mathrm{C}$ for 24 hours. The standard antibiotic discs (ciprofloxacin (CIP), levofloxacin (LE), streptomycin (S), ampicillin (AM)) were used as positive control and only the solvents alone were used as a negative control.

\section{Impregnated disc methods}

Plant extracts have been used to impregnate sterilized $6 \mathrm{~mm}$ blank discs for all solvents. After inoculation, the plates were incubated for 24 hours at $37^{\circ} \mathrm{C}$. The diameter of inhibition zone was measured for the antibacterial activity assessment.

\section{Agar well diffusion method}

Six wells were prepared for each plate. Each hole was filled with the plant extracts and the Petri dishes were left at room temperature for 2 hours for diffusion and solidification. They were incubated at $37^{\circ} \mathrm{C}$ for $24 \mathrm{hr}$. After this incubation period the diameter of the inhibition zones were measured and recorded.

\section{Synergistic activity of 0 . suave and antibiotics}

In this study, a disc-agar diffusion technique was performed to demonstrate the synergistic activity of $O$. suave with the respective antibiotics. Antibiotic discs were discretely impregnated with $50 \mu \mathrm{L}$ of different plant extracts and put on inoculated agar plates. The zones of inhibition produced by the plant extract in combination with standard antibiotics after overnight incubation was measured. The synergistic activity as described by Saquib et al.,17.

\section{Activity Index}

The inhibitory effects of the methanolic, ethanolic and distilled water extracts were calculated and compared by measuring the activity index using the following formula ${ }^{18}$.

Activity index $=\frac{\text { Zone of inhibition of extracts }}{\text { zone of inhibition of antibiotics }}$

\section{Statistical analysis}

Each experiment was carried out in duplicate. Where applicable, the data were subjected to two-way analysis of variance (ANOVA) and the t-test were applied to compare the means of various extract parameters and Post-Hoc test was used to compare the differences between factors. P-values less than 0.05 was considered statistically significant.

\section{RESULTS}

\section{Bioactive compounds}

The biochemical assays were done to check the secondary plant metabolites present in the leaves and stem of $O$. suave. The bioactive compounds in leaves were tannins, phenols, saponins, alkaloids and steroids. Only saponins were observed in stem.

\section{Antimicrobial activity analysis}

Agar well diffusion methods and impregnated disc were used. Both methods showed almost the same results for tested bacteria strains but agar well diffusion method showed high effects compared to impregnated disc. Antimicrobial activity results of $O$. suave extracts showed that, there is no inhibition zone in stem extracts for both agar well diffusion and impregnated disc methods. All leave extracts inhibited the growth of six bacteria, with inhibition zones ranging from 8.5 to $26 \mathrm{~mm}$. S. aureus 43300 and K. oxytoca 700524 were the most susceptible species to leave extracts. However, the remaining five bacteria resisted to leave extracts (Table 1). 
Table 1: Antimicrobial susceptibility analysis of 0 . suave plant extracts against 11 human pathogenic bacterial.

\begin{tabular}{|c|c|c|c|c|c|c|c|c|}
\hline \multirow[t]{3}{*}{ Species } & \multicolumn{8}{|c|}{ Inhibition zones in Millimeter (mm) } \\
\hline & \multicolumn{2}{|c|}{ Distilled water } & \multicolumn{2}{|c|}{ Methanol } & \multicolumn{2}{|c|}{ Ethanol } & \multicolumn{2}{|c|}{ Petroleum ether } \\
\hline & AWD & ID & AWD & ID & AWD & ID & AWD & ID \\
\hline E. coli 25922 & 14.75 & 14.5 & 11.75 & 13.5 & 11.5 & 11.75 & 10.5 & 9.5 \\
\hline E. coli 35218 & 0 & 0 & 0 & 0 & 0 & 0 & 0 & 0 \\
\hline H. influenza 9007 & 0 & 0 & 0 & 0 & 0 & 0 & 0 & 0 \\
\hline K. oxytoca 700524 & 23.5 & 21.5 & 20 & 20.5 & 19.25 & 19.5 & 14 & 13.75 \\
\hline P. aeruginosa 27853 & 20 & 19 & 19 & 18.5 & 18 & 18 & 12 & 13.5 \\
\hline S. Pyogene 12344 & 0 & 0 & 0 & 0 & 0 & 0 & 0 & 0 \\
\hline S. aureus 29213 & 0 & 0 & 0 & 0 & 0 & 0 & 0 & 0 \\
\hline S. aureus 43300 & 26 & 24 & 23.5 & 24.25 & 22.5 & 22.25 & 16.25 & 16.5 \\
\hline S. pneumonia 49618 & 9 & 9 & 9.5 & 9 & 9 & 9 & 8.5 & 8.75 \\
\hline S. pyogene 2399 & 12.5 & 12.5 & 11 & 11.5 & 12.5 & 12 & 11.5 & 12 \\
\hline S. sonei 25931 & 0 & 0 & 0 & 0 & 0 & 0 & 0 & 0 \\
\hline
\end{tabular}

AWD: Agar Well Diffusion;

ID: Impregnated Discs

Distilled water leave extracts were the most effective extracts and showed a strong antibacterial activity against human pathogenic bacteria. There was no inhibition zone observed in solvents used as negative control (figure 1).

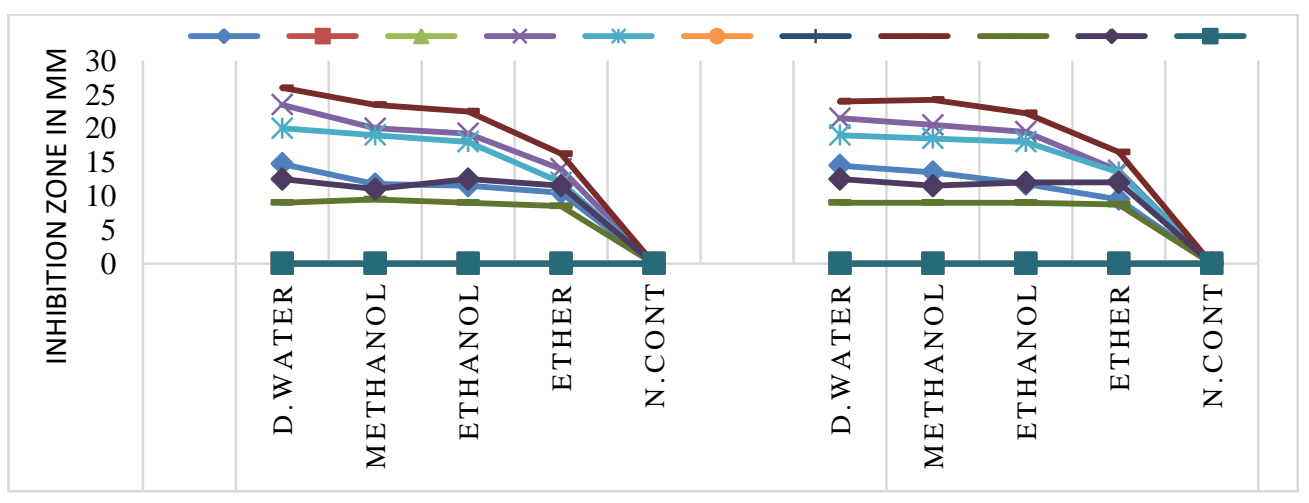

Figure 1: Inhibition zone of agar well diffusion and impregnated disc methods.

D. Water: Distilled water; N. Cont: negative control; AGAR. W.D: Agar well diffusion; I. DISC: Impregnated disc

\section{Comparison of plants extract and standards antibiotics}

All bacteria were susceptible to all standard antibiotics except $K$. oxytoca and P. aeruginosa which resisted to ampicillin. When the activities of $O$. suave was compared with these standard antibiotics, the distilled water crude extract showed better antibacterial activity against almost all bacteria strain than streptomycin except $S$. pneumonia, but least activity than levofloxacin and ciprofloxacin. Methanol, ethanol and petroleum ether active crude extracts showed lower antibacterial activity against almost all bacteria strain than all standard antibiotics (figure 2).

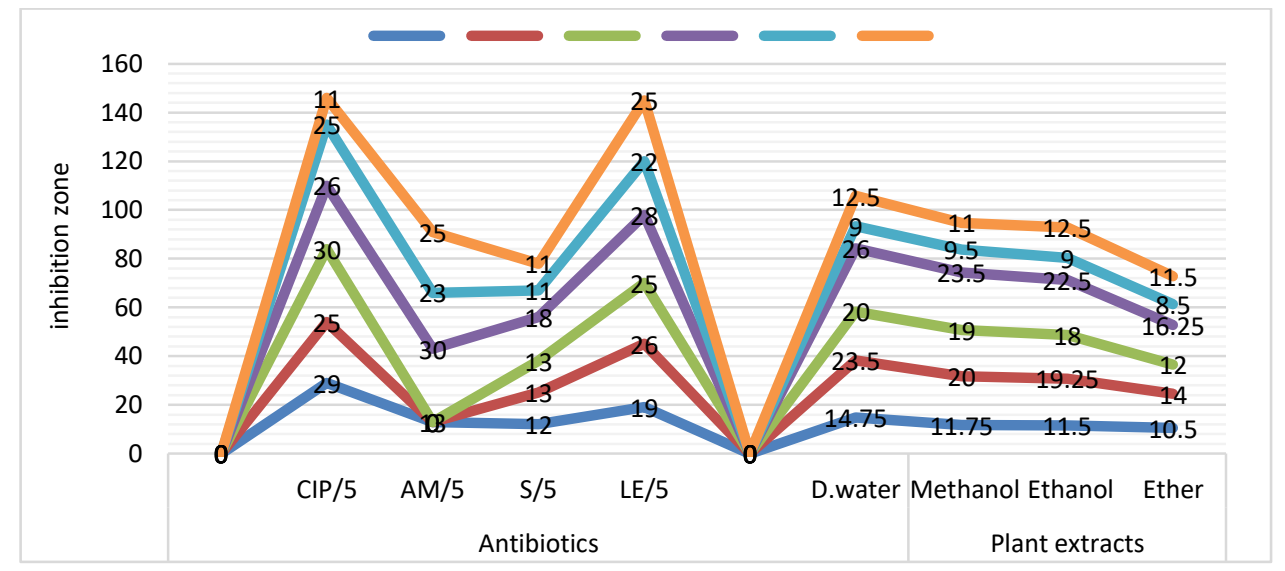

Figure 2: Inhibition zones of antibiotics vs plant extracts. 
Methanol, distilled water, ethanol and petroleum ether revealed statistically significant difference when compared with ciprofloxacin and levofloxacin using Student's t-test with P- value of $0.041,0.035,0.002$ respectively. Similarly, methanol, ethanol and petroleum ether exhibited non-statistically significant difference compared with ampicillin and streptomycin.

\section{Synergistic activity of plant extracts with antimicrobial agents}

The synergistic activity of individual plant in combination with antibiotics as well as activity index is presented below.

When distilled water extract was used in combination with streptomycin, it showed strong synergistic activity against $E$. coli and S. pneumonia. Combination of distilled water extract with levofloxacin, ciprofloxacin, amoxicillin revealed antagonism for all bacteria strains. Combination of methanol extract with amoxicillin and streptomycin showed a synergistic outcome against $P$. aeroginosa and $S$. pneumonia respectively. The rest combination showed antagonism and there was no additive observed. Combination of ethanol and petroleum ether extracts with all antibiotics showed antagonism, no additive and synergistic was observed in both solvents.

\section{Activity index}

The activity index of extracts with the standard antibiotics is presented in table 2 . Using ciprofloxacin as standard, high indices greater than unit ( $\mathrm{AI}>1)$ were observed in $S$. pyogene for all the extracts and $S$. aureus for distilled water, $S$. pyogene showed great indices of 1.13 in distilled water. With amoxicillin as a standard all extracts had indices less than unity $(\mathrm{AI}<1)$ on almost all bacteria strain except $E$. coli 25922 . Using streptomycin as a standard all bacteria showed high index greater than or equal to unity (AI>1) except $E$. coli 25922 and S. pneumonia 49618. Levofloxacin showed indices less than unit $(\mathrm{AI}<1)$ for all bacteria.

Table 2: Synergistic antimicrobial activity of $O$. suave with different antimicrobial agents

\begin{tabular}{|c|c|c|c|c|c|c|c|c|}
\hline \multirow[t]{2}{*}{$\begin{array}{l}\text { Bacteria } \\
\text { strains }\end{array}$} & \multirow[t]{2}{*}{ Antibiotics } & \multirow[t]{2}{*}{$\begin{array}{c}\text { Zone of } \\
\text { Inhibition of } \\
\text { Antibiotics }\end{array}$} & \multicolumn{2}{|c|}{$\begin{array}{c}\text { Mean Zone of } \\
\text { Inhibition of } O \text {. suave } \\
\text { extracts }\end{array}$} & \multirow[t]{2}{*}{$\begin{array}{l}\text { Mean Zone of } \\
\text { Inhibition of } \\
\text { combination }\end{array}$} & \multirow[t]{2}{*}{$\begin{array}{l}\text { Synergetic } \\
\text { activity }\end{array}$} & \multicolumn{2}{|c|}{ Activity index } \\
\hline & & & Water & Methanol & & & Water & Methanol \\
\hline \multirow{4}{*}{$\begin{array}{l}\text { E. coli } \\
25922\end{array}$} & CIP & 29 & 14.75 & 11.75 & 20 & Antagonism & 0.5 & 0.4 \\
\hline & $\mathrm{AM}$ & 13 & & & 13 & Antagonism & 1.13 & 0.9 \\
\hline & $S$ & 12 & & & 27 & Synergism & 1.22 & 0.97 \\
\hline & LE & 19 & & & 19 & Antagonism & 0.77 & 0.61 \\
\hline \multirow{4}{*}{$\begin{array}{l}\text { K. oxytoca } \\
700524\end{array}$} & CIP & 25 & 23.5 & 20 & 27 & Antagonism & 0.94 & 0.8 \\
\hline & $\mathrm{AM}$ & 0 & & & 22 & Antagonism & $\mathrm{N} / \mathrm{A}$ & $\mathrm{N} / \mathrm{A}$ \\
\hline & $S$ & 13 & & & 16 & Antagonism & 1.8 & 1.53 \\
\hline & LE & 26 & & & 22 & Antagonism & 0.9 & 0.76 \\
\hline \multirow{4}{*}{$\begin{array}{l}\text { P.aeroginos } \\
\text { a } 27853\end{array}$} & CIP & 30 & 20 & 19 & 20 & Antagonism & 0.66 & 0.63 \\
\hline & $\mathrm{AM}$ & 0 & & & 19 & Antagonism & $\mathrm{N} / \mathrm{A}$ & $\mathrm{N} / \mathrm{A}$ \\
\hline & $S$ & 13 & & & 18 & Antagonism & 1.53 & 1.46 \\
\hline & LE & 25 & & & 24 & Antagonism & 0.8 & 0.76 \\
\hline \multirow{4}{*}{$\begin{array}{c}\text { S. aureus } \\
43300\end{array}$} & CIP & 26 & 26 & 23.5 & 18 & Antagonism & 1 & 0.9 \\
\hline & $\mathrm{AM}$ & 30 & & & 15 & Antagonism & 0.8 & 0.78 \\
\hline & S & 18 & & & 14 & Antagonism & 1.44 & 1.3 \\
\hline & LE & 28 & & & 19 & Antagonism & 0.92 & 0.83 \\
\hline \multirow{4}{*}{$\begin{array}{c}S . \\
\text { pneumonia } \\
49618\end{array}$} & CIP & 25 & 9 & 9.5 & 14 & Antagonism & 0.36 & 0.38 \\
\hline & $\mathrm{AM}$ & 23 & & & 8 & Antagonism & 0.39 & 0.41 \\
\hline & S & 11 & & & 24 & Synergism & 0.81 & 0.86 \\
\hline & LE & 22 & & & 14 & Antagonism & 0.4 & 0.43 \\
\hline \multirow{4}{*}{$\begin{array}{c}\text { S. pyogene } \\
2399\end{array}$} & CIP & 11 & 12.5 & 11 & 19 & Antagonism & 1.13 & 1 \\
\hline & $\mathrm{AM}$ & 25 & & & 10 & Antagonism & 0.5 & 0.44 \\
\hline & $S$ & 11 & & & 11 & Antagonism & 1.13 & 1 \\
\hline & LE & 25 & & & 9 & Antagonism & 0.5 & 0.44 \\
\hline
\end{tabular}




\section{DISCUSSION}

Antimicrobial resistance is becoming a serious public health problem and remain the major cause of death throughout the world. Alternative natural products of plants are known to have antimicrobial properties and could be of high interest in the therapy of microbial infections and reduction of the increasing incidence of antibiotic resistance ${ }^{19}$. Various studies have been conducted in different countries, and have demonstrated the efficacy of this type of treatment 20,21 .

The phytochemical screening of $O$. suave leaves and stem revealed the presence of flavonoids, saponins, phenols, tannins and steroids for leaves and only saponins in stem and those results are in agreement with previous reports done by Tan et al.,22. These classes of compounds are known to show curative activity against several pathogens and therefore could explain its wide usage traditionally for the treatment of wide array of illnesses ${ }^{23}$.

Extracts of leaves and stem of 0 . suave from different solvents were investigated to evaluate their antimicrobial activity against human pathogenic bacteria, including Gram-positive bacteria ( $S$. aureus and $S$. pyogene) and Gram- negative bacteria (E. coli, S. typhi, S. pneumonia, K. oxytoca, $H$. influenza and $P$. aeruginosa) using agar well diffusion and impregnated disc methods.

The high inhibition zone observed in extract of distilled water could be due to the presence of high amount of polar bioactive compounds compared to than non-polar compounds 24 . Important to note, no inhibition zone appeared on wells with solvents only (controls). Thus, the inhibition observed in plant leaves extract was due to bio-active compounds present in $O$. suave leaves. However, stem extracts didn't show any activity against all bacteria strain. This could be due to the presence of only one compound (saponins) among seven tested bio-active compounds.

S. aureus ATCC 43300 was highly sensitive bacteria followed by $K$. oxytoca 700524 and the lowest sensitive was $S$. pneumonia 49618. S. pyogene ATCC 12344, S. Sonei ATCC 25931, S. aureus ATCC 29213, H. influenza ATCC 9007and E. coli ATCC 35218 resisted to all plant extracts (Table 1).

Impregnated disc method showed low activity against sensitive tested bacteria, while agar well diffusion showed high activity against sensitive tested bacteria, and this is due to paper disc retention properties 25 .

Meanwhile, the comparison with standards antibiotics showed that the distilled water extract exhibited much higher activity against all tested organisms than activity of streptomycin. Antibacterial activity of the standard antibiotics can be magnified by the combination of phytopharmaceuticals and modern medication ${ }^{26}$. In addition, the combination may be helpful in the preclusion of the emergence of resistant bacteria and reducing the drug toxicity ${ }^{27}$. Various in vitro experiments have established the fact that a combination of plant extracts and antibiotics possess a synergistic effect, which results in a significant decrease in levels of minimum inhibitory concentration for the antibiotics 28,29 .

The findings from the present study may help to understand the synergistic effect of combination therapy which could provide a new strategy for the adjunctive treatment for infections. Results from the current study revealed that a combination of distilled water and methanol extracts with streptomycin revealed synergistic activity against $E$. coli 25922 and S. pneumonia 49618. The above findings are in agreement with the previous study, in which the author had reported synergism between plant extract and antibiotics against Gram positive and Gram negative bacteria ${ }^{30}$.

The plant extracts have shown higher activity index values against almost all tested bacteria strains in CIP and S which means that the extracts had good activity compared to those standard antibiotics. The high activity indices of the crude extracts is an indication of more promising therapeutic activity of the plants ${ }^{31}$.

\section{CONCLUSION}

Leaves of 0 . suave showed a great potential activity in the inhibition of several bacterial strains and this should be fully explored in proper approach. Indeed, the aqueous crude of $O$. suave leaves had a great potential to inhibit Gram positives as well as Gram negatives bacteria. Further studies on other parts of the plant are recommended for better conclusive recommendations. In addition, antimicrobial analyses should be conducted on other species of bacteria and eventually on fungi strains.

\section{Acknowledgments}

The authors gratefully thank the support of staff members of Chemistry and Microbiology laboratories of INES-Ruhengeri for their assistance.

\section{Declaration of interest statement}

The authors have no conflicts of interest to declare.

\section{Funding}

This work was carried out with the financial support from Government of Rwanda through National Council for Science and Technology.

\section{REFERENCES:}

1. Leekha S, Terrell CL, Edson RS. General principles of antimicrobial therapy. Mayo Clin Proc. 2011; 86(2):156-67. https://doi.org/10.4065/mcp.2010.0639

2. Maillard J, Bloom SF, Courvalin P, Essack SY, Gandra S, Gerba CP, et al. Reducing antibiotic prescribing and addressing the global problem of antibiotic resistance by targeted hygiene in the home and everyday life settings: A position paper. Am J Infect Control. 2020; 48:1090-1099. https://doi.org/10.1016/j.ajic.2020.04.011

3. Akinde 0, Taiwo M. Emerging antibiotic resistance in Africa, threat to healthcare delivery. MOJ Biol Med. 2017; 1(4):114-5. https://doi.org/10.15406/mojbm.2017.01.00023

4. Damlin A, Sharma M, Marrone G, Stålsby Lundborg C. Antibiotic prescribing among patients with severe infectious diseases in two private sector hospitals in Central India - A time series analysis over 10 years. BMC Infect Dis. 2020; 20(1):1-13. https://doi.org/10.1186/s12879-020-05059-7

5. Elton L, Thomason MJ, Tembo J, Velavan TP, Pallerla SR, Arruda LB, et al. Antimicrobial resistance preparedness in sub-Saharan African countries. Antimicrob Resist Infect Control. 2020; 9(1):111. https://doi.org/10.1186/s13756-020-00800-y

6. Madureira AM, Ramalhete C, Mulhovo S, Duarte A, Ferreira MJU. Antibacterial activity of some African medicinal plants used traditionally against infectious diseases. Pharm Biol. 2012; 50(4):481-9. https://doi.org/10.3109/13880209.2011.615841

7. Mahomoodally MF. Evidence based complementary and alternative medicine traditional medicines in Africa : an appraisal of ten potent African medicinal plants. Evidence-based Complement Altern Med [Internet]. 2013; 2013:1-14. https://doi.org/10.1155/2013/617459

8. Bouyahya A, Dakka N, Et-Touys A, Abrini J, Bakri Y. Medicinal plant products targeting quorum sensing for combating bacterial 
infections. Asian Pac J Trop Med [Internet]. 2017 Aug; 10(8):72943. https://doi.org/10.1016/j.apjtm.2017.07.021

9. Vadhana P, Singh BR, Bharadwaj M. Emergence of herbal antimicrobial drug resistance in clinical bacterial isolates. Pharm Anal Acta. 2015; 6(10). https://doi.org/10.4172/21532435.1000434

10. Vlietinck AJ, Van Hoof L, Totté J, Lasure A, Berghe D Vanden, Rwangabo PC, et al. Screening of hundred Rwandese medicinal plants for antimicrobial and antiviral properties. J Ethnopharmacol. 1995; 46(1):31-47. https://doi.org/10.1016/0378-8741(95)01226-4

11. Runyoro D, Ngassapa O, Vagionas K, Aligiannis N, Graikou K, Chinou I. Chemical composition and antimicrobial activity of the essential oils of four Ocimum species growing in Tanzania. Food Chem [Internet]. 2010; 119(1):311-6.

https://doi.org/10.1016/j.foodchem.2009.06.028

12. Pandey AK, Singh P, Tripathi NN. Chemistry and bioactivities of essential oils of some Ocimum species: an overview. Asian Pac J Trop Biomed. 2014; 4(9):682-94. https://doi.org/10.12980/APJTB.4.2014C77

13. Opiyo SA. Insecticidal activity of Ocimum Suave willd extracts and compounds against Sitophilus Zeamais Motschulsky. Basic Sci Med. 2020; 9(2):32-7.

14. Kiraithe MN, Nguta JM, Mbaria JM, Kiama SG. Evaluation of the use of Ocimum suave willd. (Lamiaceae), Plectranthus barbatus Andrews (Lamiaceae) and Zanthoxylum chalybeum Engl. (Rutaceae) as antimalarial remedies in Kenyan folk medicine. J Ethnopharmacol [Internet]. 2016; 178:266-71. https://doi.org/10.1016/j.jep.2015.12.013

15. Janssen AM, Scheffer JJC, Ntezurubanza L, Svendsen AB. Antimicrobial activities of some Ocimum species grown in rwanda. J Ethnopharmacol. 1989; 26(1):57-63. https://doi.org/10.1016/0378-8741(89)90113-X

16. Harborne JB. Phytochemical methods. a guide to modern tehniques of plant analysis. Vol. 37, Brittonia. 1985. 309 p. https://doi.org/10.2307/2806080

17. Saquib SA, Alqahtani NA, Ahmad I. Evaluation and comparison of antibacterial efficacy of herbal extracts in combination with antibiotics on periodontal pathobionts : an in vitro microbiological study. Antibiotics. 2019; 8(3):1-12.

https://doi.org/10.3390/antibiotics8030089

18. Esther N, Fatima T, Ediga B A. Evaluation of activities of some plant leaf extract on typhoidal and non-typhoidal Salmonella isolate from selected hospitals in Bauchi, Nigeria. GSC Biol Pharm Sci. 2020; 11(2):020-30.

https://doi.org/10.30574/gscbps.2020.11.2.058

19. Gupta PD, Birdi TJ. Development of botanicals to combat antibiotic resistance. J Ayurveda Integr Med [Internet]. 2017; 8(4):266-75. https://doi.org/10.1016/j.jaim.2017.05.004
20. Akindele P, Fatunla O, Ibrahim K, Afolayan C. Antibacterial and phytochemical screening of calotropis procera leaf extracts against vancomycin and methicillin resistant bacteria isolated from wound samples in hospital patients. J Complement Altern Med Res. 2017; 2(1):1-14.

https://doi.org/10.9734/JOCAMR/2017/30975

21. Khameneh B, Iranshahy M, Soheili V, Sedigheh B, Bazzaz F. Khameneh2019.Pdf. Antimicrob Resist Infect Control. 2019; 8:128. https://doi.org/10.1186/s13756-019-0559-6

22. Tan P V., Mezui C, Enow-Orock GE, Agbor G. Antioxidant capacity, cytoprotection, and healing actions of the leaf aqueous extract of Ocimum suave in rats subjected to chronic and cold-restraint stress ulcers. Ulcers. 2013; 2013:1-9.

https://doi.org/10.1155/2013/150780

23. Abdisa Z, Kenea F. Phytochemical screening, antibacterial and antioxidant activity studies on the crude root extract of Clematis hirsuta. Cogent Chem [Internet]. 2020; 6(1):1862389. https://doi.org/10.1080/23312009.2020.1862389

24. Ajayi AM, Naluwuge A, Buyinza P, Luswata I. Comparative physicochemical, phytochemical and acute toxicity studies of two Ocimum species in Western Uganda. J Med Plants Res. 2017; 11(1):1-10. https://doi.org/10.5897/JMPR2015.6025

25. Balouiri M, Sadiki M, Ibnsouda SK. Methods for in vitro evaluating antimicrobial activity: a review. J Pharm Anal [Internet]. 2016; 6(2):71-9. https://doi.org/10.1016/j.jpha.2015.11.005

26. Ahn K. The worldwide trend of using botanical drugs and strategies for developing global drugs. BMB Rep. 2017; 50(3):1116. https://doi.org/10.5483/BMBRep.2017.50.3.221

27. Okoh AI, Aiyegoro OA. Use of bioactive plant products in combination with standard antibiotics: Implications in antimicrobial chemotherapy. J Med Plants Res. 2009; 3(13):114752.

28. Sharif SA, Ismaeil AS, Ahmad AA. Synergistic effect of different plant extracts and antibiotics on some pathogenic bacteria. Sci J Univ Zakho. 2020; 8(1):7-11.

https://doi.org/10.25271/sjuoz.2020.8.1.653

29. Betoni JEC, Mantovani RP, Barbosa LN, Di Stasi LC, Fernandes A. Synergism between plant extract and antimicrobial drugs used on Staphylococcus aureus diseases. Mem Inst Oswaldo Cruz. 2006; 101(4):387-90. https://doi.org/10.1590/S007402762006000400007

30. Stefanović OD. Synergistic activity of antibiotics and bioactive plant extracts: a study against Gram-positive and Gram-negative bacteria. Bact Pathog Antibact Control. 2018; https://doi.org/10.5772/intechopen.72026

31. Prabhu KS, Lobo R, Shirwaikar AA, Shirwaikar A. Ocimum gratissimum: a review of its chemical, pharmacological and ethnomedicinal properties. Open Complement Med J. 2009; 1(1):1-15. https://doi.org/10.2174/1876391X00901010001 